\title{
KETERAMPILAN DASAR MENGAJAR PADA MAHASISWA SEMESTER 6C PROGRAM STUDI PENDIDIKAN EKONOMI UNIVERSITAS PAMULANG (Studi Analisis Keterampilan Menjelaskan)
}

\author{
SOFFI SOFFIATUN ${ }^{1)}$, RUSMAINI ${ }^{2)}$ \\ ${ }^{1,2}$ Dosen Pendidikan Ekonomi, Universitas Pamulang \\ dosen00762@unpam.ac.id ${ }^{1}$,dosen02006@unpam.ac.id ${ }^{2}$
}

\begin{abstract}
ABSTRAK
Mengajar adalah salah satu tugas guru dalam melakukan proses pembelajaran dan mengajar juga menjadi salah satu kunci keberhasilan dalam menyerap materi oleh peserta didik. Ada 8 keterampilan mengajar yang harus dikuasi oleh calon guru sebagai bekal untuk dapat mengajar dengan baik. Salah satunya adalah keterampilan menjelaskan, dalam keteampilan menjelaskan ini calon guru dan guru dituntut untuk mampu menjadi penterjemah Bahasa buku yang baik sehingga mudah dipahami oleh peserta didik. Kemempuan para mahasiswa dalam menjelaskan masih dinilai kurang memuaskan untuk itu peneliti melakukan penelitian dengan tujuan 1) untuk menggali lebih dalam kendalakendala mahasiswa ketika memparaktekkan keterampilan menjelaskan, dan memberikan solusi untuk meminimalisir kelemahan tersebut. 2) Dalam penelitian ini menggunakan pendekatan deskriptif dan metode penelitian kualitatif. 3) Teknik analisis data yang digunakan pada penelitian ini yaitu pengumpulan data, reduksi data, penyajian data dan penarikan kesimpulan. 4) pada penelitian ini ditemukan bahwa dalam keterampilan menjelaskan mahasiswa belum bisa memahami materi yang akan disampaikan, tidak bisa mengembangkan materi, malas untuk membaca dan malas mengikuti perkembangan-perkembangan terbaru yang berkaitan dengan materi.5) dari hasil penelitian dapat disimpulkan bahwa mahasiswa pada semester 6 ini belum dapat dikatakan terampil dalam melaksanakan keterampilan mengajar pada keterampilan menjelaskan
\end{abstract}

Kata Kunci: keterampilan dasar mengajar, keterampilan menjelaskan 


\section{PENDAHULUAN}

Pada dasarnya setiap orang adalah guru, karena disadari ataupun tidak disadari baik langsung maupun tidak langsung setiap orang bisa memberikan informasi baik itu berupa pengetahuan maupun keterampilan kepada orang lain, terlepas dari apakah yang menerima pengetahuan dan keterampilan tersebut dapat memahami atau tidak. Namun berbeda dengan halnya dengan seorang guru. Guru dituntut untuk bisa melakukan hal yang lebih dari sekedar seorang individu yang hanya sekedar melakukan transfer informasi. Bukan hal yang mudah untuk menjadi seorang guru.

Menurut UU NO 14 tahun 2005 guru adalah pendidik professional dengan tugas utama mendidik, mengajar, membimbing, mengarahkan, melatih, menilai dan mengevaluasi peserta didik pada Pendidikan usia dini jalur Pendidikan formal, Pendidikan dasar, dan Pendidikan menengah. Sedangkan menurut Dari pengertian tersebut dapat dijabarkan bahwa menjadi seorang guru harus memiliki kemampuan yang baik untuk dapat menjalankan tugas-tugasnya. Untuk mendukung tugas tersebut guru dituntut untuk memiliki 4 kompetensi yang harus dikuasi antara lain 1) kompetensi pedagogic, 2) kompetensi kepribadian, 3) kompetensi social, 4) kompetensi professional.
Dari empat komeptensi tersebut ada salah satunya yang menjadi kunci utama keberhasilan peserta didik dalam menerima dan menyerap informasi ilmu, pengetahuan dan keterampilan. Adalah kompetensi pedagogic yang di dalamnya terdapat kompetensi guru dalam mengajar yaitu Keterampilan Dasar Mengajar. Ada 8 keterampilan dasar mengajar yang harus dikuasi oleh calon guru dan guru. Salah satunya adalah keterampilan menjelaskan. Keterampilan menjelaskan ini menjadi inti dari proses pembelejaran yang berlangsung selama di kelas. Dalam keterampilan ini calon guru dan guru dituntut untuk mampu menterjemahkan suatu materi kepada peserta didik hingga peserta didik benar-benar memahami, mempraktekkannya bahkan mengaplikasinanya dalam kehidupan sehari-hari.

Bukan hal yang mudah bagi calon guru dan guru untuk bisa membuat peserta didiknya paham terhadap suatu materi pelajaran. Fenomena yang terjadi adalah masih banyak peserta didik yang memberikan penilaian bahwa gurunya dalam menjelaskan sulit untuk dipahami sehingga peserta didik merasa tidak mengetahui apapun yang disampaiakan oleh gurunya. Tentunya hal ini akan membawa hasil belajar yang tidak baik bagi peserta didik. Kondisi seperti ini tidak dapat diabaikan, 
karena bagaimanapun juga keberhasilan Pendidikan juga salah satunya dipengaruhi oleh keterampilan gurunya dalam mengajar. Salah satunya yaitu keteramdpilan menjelaskan. Keterampilan menjelaskan adalah keterampilan seorang guru dalam menyampaiakn berbagai informasi secara sistematis dengan Bahasa lisan yang dapat dengan mudah dipahami oleh peserta didiknya. Dengan demikian dapat dikatakan bahwa ketermapilan menjelaskan menjadi hal penting $\mathrm{h}=\mathrm{yang}$ harus dikuasi oleh calon guru dan guru.

Ketidakmampuan dalam menjelaskan juga terjadi pada mahasiswa calon guru praktikan disemester 6 yang berperan sebagai peserta didik mengatakan bahwa ketika temannya praktek menjelasakn materi, mereka masih merasa bingung dan tidak paham apa yang disampaikan oleh temannya yang berperan sebagai guru. Dalam ketreampilan menjelaskan salah satu indicator keberhasilannya adalah dengan ditandai yang mendengarkan penjelasan materi tersebut dapat memahami yang kemudian jika diberikan umpan balik maka respon dari peserta didik akan positif.

Dari hal tersebut maka peneliti merasa tertarik untuk melakukan penelitian dengan focus penelitian yaitu keterampilan dasar mengajar pada mahasiswa semester 6 program studi Pendidikan ekonomi
UNPAM (studi analisis keterampilan menjelaskan)

\section{METODE PENELITIAN}

Dalam penelitian ini peneliti memilih menggunakan meteode penelitian ini kualitatif berjenis studi kasus. Data yang digunakan tidak berupa angka namun menggunakan suatu penggambaran yang diperoleh melalui hasil wawancara, catatan lapangan, catatan pribadi dan dokumentasi lainnya. Dari metode penelitan tersebut maka tujuannya adalah menggambarkan kejadiankejadian yang sebenarnya keadaan pada mahasiswa semester 6 tentang bagaimana kemampuan mereka dalam memparaktekkan keterampilan menjelaskan. Penelitian ini juga menghasilkan data deskriptif yaitu berupa kata-kata atau lisan dari orang-orang dan perilaku yang diamati (Moloeng, 2011:4).

Dalam penelitian ini Teknik pengumpulan datanya sejalan dnegan pendapat Sugiyono (2011:309) bahwa Teknik pengumpulan data dalam penelitian kualitatif secara umum terdiri dari empat macam yaitu, observasi, wawancara, dokumentasi dan gabungan/triangulasi. Triangulasi adalah pengecekan data dari berbagai sumber dengan berbagai cara dan berbagai waktu (Sugiyono, 2011:372).

Penelitian ini dilakukan pada mahasiswa semester 6 Program Studi Pendidikan Ekonomi Universitas 
Pamulang yang telah menempuh mata kuliah Keterampilan Dasar Mengajar. Waktu pelaksanaan peneletian ini pada bulan Oktober sd November 2019. Subjek dalam penelitian ini adalah berjumlah 6 orang. Pemilihan 6 orang mahasiswa ini sebagai sumber data berdasarkan purposive sampling. Sedangkan untuk pengumpulan data dilakukan pada kondisi yang natural yaitu di mana sumber data tidak mengetahui jika sedang dijadikan subjek penelitian.

Dalam hal ini peneliti menggunakan jenis observasi partisipasi pasif. Peneliti melakukan dokumentasi kegiatan praktek mengajar menggunakan lembar observasi dan rekaman video dnegna alat rekam berupa hand phone (HP), sebagai antisipasi adandya informasi yang terlewat pada saat peneliti melakukan pengmabilan data. Dalam pengambilan data ini peneliti focus pada salah satu keterampilan dasar mengajar yaitu keterampilan menjelaskan.

Dalam pengambilan data peneliti melakukannya sebanyak 3 kali sehingga dihasilkan 3 rekaman dan 3 lembar observasi dalam praktek mengajar keterampilan menjelaskan materi pelajaran Ekonomi SMA. Selain itu peneliti juga melakukan wawancara terbuka dan semi terstruktur yaitu wawancara yang dilakukan dengan cara sumber data tidak tahu jika sedang diwawancara yang pada saat melakukan wawancara peneliti melakukan perekaman hasil wawancara dengan menggunakan alat hand phone (HP). Wawancara ini dilakukan untuk menunjang data utama.

Dalam melakukan analisis data langkah yang dilakukan oleh peneliti yaitu dengan melakukan pengkajian seluruh data yang tersedia dadri lembar observasi dan hasil rekaman ketika praktek mengajar yang didukung dengan hasil wawancara. Pada penelitian ini dilakukan tiga tahap analisis data kualitatif hal ini sejalan dengan pendapat Miles dan Huberman yaitu reduksi data, penyajian data, dan penarikan kesimpulan. Peneliti menuajikan data dalam bentuk gteks narasi, sedangkan penarikan kesimpulan didasarkan pada hasil pengambilan data pada saat kegiatan praktek mengajar dan hasil wawancara pada mahasiswa sebagai subjek penelitian yang sedang praktek mengajar. Adapun uji validitas inernal dilaksanakan dengan pengecekan anggota (member chek). Pengecekan ini dilakukan setelah mendapat temuan atau kesimpulan dari analisis data.

\section{HASIL DAN PEMBAHASAN}

Berdasarkan analysis data hasil observasi yang didukung dnegna wawancara maka diperoleh hasil analisis untuk mahasiswa sebagai sumber data RK1, RK2, RK3, RK4, RK5, RK6. 
Keterampilan Menjelaskan.

Subjek RK1, dalam keterampilan menjelaskan subjek RK1 mengawali dengan memberikan pertanyaan kepada peserta didik tentang pengetahuan awal materi yang akan dijelaskan, dalam pengajuan pertanyaan ini subjek mengajukan pertanyaan sudah sesuai dengan komponen dalam memberikan pertanyaan. Sementara itu pada saat menjelaskan materi subjek menyampaikan belum secara terstruktur dan sistematis, Bahasa yang digunakanpun masih terdengar berbelit-belit, sesekali melihat pada buku teks, suara cukup terdengar, tempo/kecepatan dalam lisan terdengar agak cepat sehingga sesekali peserta didik minta diulangi dalam menjelaskan, kemudian dalam memberikan contoh-contoh sangat actual sesuai dengan kondisi yang ada, memberikan penekanan pada bagian-bagian yang dianggap penting pada materi tersebut. Ketika subjek memberikan umpan balik kepada peserta didik hanya sebagian kecil peserta didik yang dapat menjawab pertanyaan subjek.

Subjek RK2, dalam keterampilan menjelaskan subjek langsung membagikan beberapa gambar kepada siswa yang berkaitan dengan materi yang akan dijelaskan. Menjelaskan materi belum terstruktur, dengan volume suara yang lemah dan temponya pun lambat, tidak memberikan penekanan pada bagian-bagian yang dianggap penting, sehingga peserta didik cenderung tidak memperhatikan asyik ngobrol sendiri, tidak dapat mengembangkan materi subjek terlihat masih menghafal materi sesuai dengan buku referensi yang digunakan, contoh-contoh yang diberikan sangat kurang, subjek juga terlihat gagap dan tersendat-sendat dengan ditandai banyak sekali mengeluarakat huruf "eeee", ketika memberikan umpan balik peserta tidak memberikan respon sama sekali.

Subjek RK3, dalam keterampilan menjelaskan nampak sekali memperlihatakan rasa percaya diri, kemudian menjelaskan mind maping yang ditempel pada papan tulis, menjelaskan materi dengan sistematis, dengan volume suara yang terdengar hingga keseluruh ruangan kelas, lancara tidak tersendat-sendat, temponya agak sedikit cepat, tidak memberikan penekanan pada bagian-bagian yang di anggap penting, Bahasa yang digunakan sederhana dan tidak berbelit-belit, pengembangan materinya up to date, dalam memberikan contoh-contoh juga sangat actual hal ini terlihat dari hamper seluruh peserta didik memperhatikan ketika subjek sedang menjelaskan materi, bahkan ada beberapa peserta didik yang mengajukan pertanyaan dengan antusias. Namun ketika memberikan jawaban atas pertanyaan yang diajukan peserta didik subjek agak 
melantur dan tidak mengarah kepada pertanyaan yang diajukan, sehingga peserta didik sedikit terlihat tidak puas atas jawaban yang diberikan subjek. Secara keseluruhan dilihat dari antusiasme peserta didik dan hasil umpan balik dapat dikatakan bahwa peserta didik mengerti dengan apa yang telah dijelaskan subjek.

RK4, dalam keterampilan menjelaskan subjek masih terlihat membawa catatan kecil dan sesekali membaca teks tersebut, menjelaskan dengan sistematis sesuai dengan urutannya, Bahasa yang digunakan banyak menggunakan Bahasa gaul dan sedikit tidak mengindahkan menggunakan Bahasa Indonesia yang baik dan benar, suara cukup lantang dan cenderung berteriak, temponya cukup tidak terlalu cepat ataupun lambat, ketika subjek menjelaskan materi lebih banyak membaca teks yang dibuat, selain itu subjek juga sering terlihat diam atau terhenti ketika menjelaskan, sehingga peserta didik banyak yang mengacuhkannya, subjek terlihat tidak siap sama sekali ketika praktek menjelaskan. Hal ini nampak pada saat baru beberapa menit berjalan subjek mengangkat tangan dan tidak mau melanjutkan untuk praktek keterampilan menjelaskan.

RK5, dalam keterampilan menjelaskan subjek terlihat sangat tegang, hal ini terdengar dari suaranya yang sedikit bergetar namun cukup lantang sehingga terdengar ke seluruh ruangan, menjelaskan materi secara sistematis, Bahasa yang digunakan sederhana sehingga mudah dipahami dan menyampaiaknya dengan lugas tidak berbelit-belit, pengembangan materinya cukup bagus dengan memasukkan materi-materi berdasarkan data-data yang konkret, dalam memberikan contohcontohpun sangat mendalam sehingga peserta didik terlihat mengerti, dan sangat menguasai materi ini terlihat pada saat ada peserta didik yang bertanya subjek dapat menjawab tanpa kesulitan dan sangat mendalam, tidak terlihat menghafalkan materi, hal ini nampak pada saat diberikan umpan balik hamper seluruh peserta didik dapat menjawab. Subjek pada saat menjelaskan cenderung menggunakan metode dari hal yang umum kemudian baru ke yang khusus sehingga selama proses pembelajaran terlihat ingteraktif yang cukup seimbang antara peserta didik dan subjek.

RK6, dalam keterampilan menjelaskan subjek mengawali dengan langsung membagikan gambar-gambar kepada peserta didik, kemudian subjek meminta peserta didik untuk menceritakan apa yang sudah dilihat pada gambar. Setelah peserta didik menceriritakan apa yang dilihat pada gambar subjek akan menjelaskan materi, ketika menjelaskan materi subjek terlihat sering berhenti terdiam seakan-akan sedang mengingat-ingat meteri, 
selain itu subjek dalam menjelaskan tidak secara sistematis, sehingga telihat alur yang tidak jelas dan peserta didik terlihat bingung dengan apa yang dijelaskan oleh subjek, Bahasa yang digunakan pun terdengar berbelit-belit, saura sangat pelan dan lambat, seing keluar huruf "mmmm", saat menjelaskan subjek lebih sering melihat gambar yang dipegangnya. Subjek juga ketika menjelaskan lebih banyak menggunakan kata-kata asing yang tidak diterjemahkan sehingga semakin membuat peserta didik nampak tidak memahami.

Apabila dilihat dari hasil lembar observasi 1 maka akan nampak dalam table sebagai berikut:

Tabel 1. Lembar Observasi 1 Kriteria keterampilan menjelaskan

\begin{tabular}{|l|l|l|l|l|}
\hline Subjek & \multicolumn{4}{l}{ Kriteria } \\
& 1 & 2 & 3 & 4 \\
\hline RK1 & KB & CB & B & KB \\
\hline RK2 & CB & TB & KB & KB \\
\hline RK3 & B & SB & CB & B \\
\hline RK4 & KB & TB & TB & KB \\
\hline RK5 & B & SB & B & SB \\
\hline RK6 & KB & KB & KB & KB \\
\hline
\end{tabular}

Keterangan Kriteria:

$1=$ menjelaskan dengan sistematis

$2=$ menjelaskan dengan menguasai materi

3 = menjelaskan dengan memberikan contoh-contoh

4 = menjelasakan dengan menggunakan Bahasa yang mudah dipahami (jelas, lugas, sederhana, tidak berbelit-belit)
Dari tabel 1 di atas tampak bahwa dalam keterampilan menjelaskan yang telah dipraktekkan oleh subjek pada saat praktek menunjukkan bahwa masih begitu banyak kelemahan yang dimiliki oleh mahasiswa terutama dalam hal kriteria menguasai materi. Kriteria menggunakan Bahasa yang baik dan benarpun pada saat praktek menjelaskan beberapa subjek belum bisa melakukan mereka lebih banyak menggunakan kata-kata gaul sebagai contoh kata "kayaknya", " bakalan", "kagak" "ngobrolin" "ngomong" dan masih banyak lagi kata-kata gaul yang tidak tepat digunakan dalam mengajar yaitu keterampilan menjelaskan.

Selain itu ketika menjelaskan subjek juga masih kesulitan memberikan contoh-contoh yang mestinya menjadi hal mudah karena materi yang disampaiakan banyak ada dalam kehidupan sehari-hari. Kelemahan lain yang diperlihatkan oleh subjek penelitian adalah tidak mengembangkan materi artinya subjek dalam menjelaskan masih terfokus hanya materi yang ada dibuku referensi yang digunakan. Hal ini terlihat dari cara menjelaskan masih terlihat menghafal. Hal ini menunjukkan bahwa mahasiswa sebetulnya belum siap untuk melakukan Praktek Pengalaman Lapangan. Meskipun sudah menempuh mata kuliah Keterampilan Dasar Mengajar (KDM) 
Keterampilan menjelaskan adalah menyajikan informasi secara lisan yang diorganisasi secara sistematis untuk menunjukkan adanya hubungan satu dengan yang lain. Ciri keberhasilan dari ketrampilan menjelaskan ini adalah bahwa setiap materi yang dijelaskan dapat dimengerti atau dipahami oleh peserta didik bahkan bisa dipraktekkan dan diimplementasikan.

Selain dari hasil lembar observasi penilaian peneliti juga memperoleh hasil penelitian dari hasil wawancara yang menjadi pendukung dalam memperoleh data terkait kelemahan-kelemahan yang dimiliki oleh subjek dalam praktek keterampilan menjelaskan. Dalam wawancara yang dilakukan oleh peneliti dapat digambarkan bahwa ada 4 responden yang mengaku kesulitan dalam memahami materi karena mereka merasa tidak hobi membaca tentang ilmu pengetahuan, mereka merasa kesulitan memahami isi dari materi, mereka juga mengatakan bahwa mereka tidak bisa membuat analisis untuk mengembangkan materi, kemudian mereka juga merasa bahwa kuliah di Pendidikan Ekonomi merupakan salah jurusan, bukan cita-cita mereka untuk menjadi guru, namun mereka tetap meneruskan karena sudah kepalang tanggung, selain itu mereka juga tidak menyangka bahwa kuliah di kependidikan itu ada kewajiban untuk praktek mengajar, sehingga dengan hal tersebut menjadikan beban yang dirasa berat bagi mahasiswa dalam menjalaninya. Tentunya hal sangat menarik bagi peneliti dengan status mereka sebagai mahasiswa Pendidikan Ekonomi ternyata mereka dalam menjalani aktivitas kuliah hanya sekedarnya.

Dari hasil wawancara tersebut jika dikaitkan dengan hasil praktek mengajar dalam hal ini keterampilan menjelaskan menunjukkan bahwa dengan ketidak seriusan mereka dalam kuliah juga memberikan kontribusi terhadap hasil praktek yang tidak memuaskan dengan kata lain ketika subjek diminta untuk mempraktekkan keterampilan mengajar menjelaskan mereka tidak maksimal atau kurang baik.

\section{KESIMPULAN}

Berdasarkan hasil analisis data dan pembahasan pada subjek penelitian yaitu mahasiswa semester 6C sejumlah 6 orang dapat disimpulkan bahwa kemampuan Keterampilan Dasar Mengajar pada keterampilan menjelaskan pada praktek mengajar mata kuliah Pemantapan Kemampuan Mengajar (PKM) adalah sebagai berikut:

1. Dalam keterampilan menjelaskan, dari empat kriteria yang ditetapkan dalam keterampilan menjelaskan yaitu, menjelasakan secara sistematis, menguasai materi, menjelasakn dengan memberikan contoh- 
contoh, menjelaskan dengan menggunakan Bahasa yang mudah dipahami (jelas, tidak berbelit-belit) dapat dikatakan bahwa mahasiswa sebagai subjek penelitian sejumlah 6 orang, 4 orang dikatakan kurang baik dalam mempraktekkannya, sehingga dikategorikan tidak siap untuk mengajar. Sedangkan 2 orang mahasiswa subjek penelitian dikategorikan baik dalam mempraktekkannya dan dikategoriakn siap untuk mengajar.

2. Kelemahan yang dimiliki oleh subjek penelitian ini disebabakan antara lain karena:1) mereka malas membaca, 2)kesulitan dalam memahami makna dari isi materi, 3)kesulitan ketika harus menganalisis hubungan suatu sebab akibat, 4) mereka tidak memiliki cita-cita untuk menjadi guru, 5)dalam menjalani kuliah di Pendidikan EKonomi hanya sekedarnya karena tidak sesuai dengan keinginan hati akibat merasa salah jurusan

\section{REFERENSI}

Buchari, Alma. (2009). Guru Profesional Menguasai Metode dan Terampil Mengajar. Bandung: Alfabetha

Djamarah. S. B, Zain. A. (2010). Strategi Belajar Mengajar. Jakarta:Rineka Cipta.
Hamdani. (2010). Kemampuan Dasar Mengajar. Jakarta:Rineka Cipta

Megler, A.G dan Tangen, DJ. (2010). Using Microteaching to Enhance Teacher Efficacy In Pre-Service Teachers. Journal of Teaching Education.

Mulyasa. (2014). Guru Dalam Implemetasi Kurikulum 2013. Bandung: Remaja Rosdakarya

Sukirman, Dadang. (2011). Perencanaaan Pembelajaran. Bandung : UPI PRESS. 